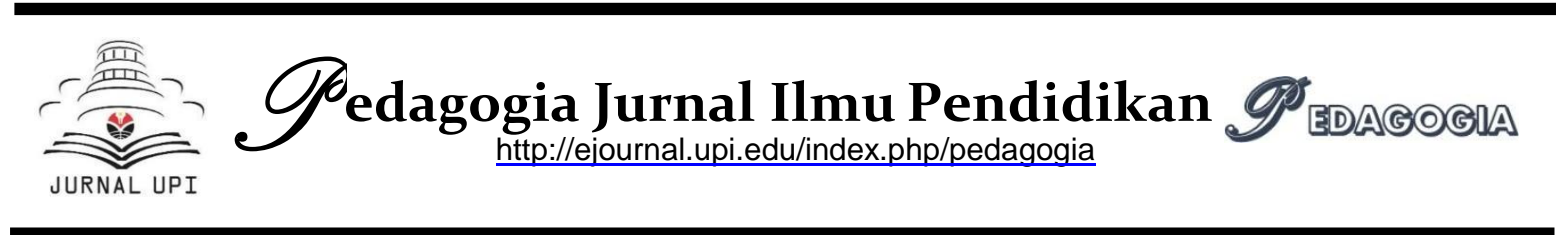

\title{
Profil Kesantunan Berbahasa Siswa pada Tingkat Sekolah Menengah Atas
}

\author{
Imas Mardiah \\ Ipah Saripah \\ Departemen Psikologi Pendidikan dan Bimbingan \\ Fakultas Ilmu Pendidikan \\ Universitas Pendidikan Indonesia \\ imasmardiah@student.upi.edu
}

\begin{abstract}
Linguistic politeness is an important skill for every individual to be able to achieve success and harmony in life. Linguistic politeness is related to individual skills in adjusting the language they use when interacting with other individuals. In another perspective, linguistic politeness is part of character strength in positive psychology, namely friendliness (agreeableness). The purpose of this linguistic politeness research is to describe linguistic politeness as one of the forms of social skills. The research employed a descriptive quantitative method to 191 tenth grade students using two types of research instruments, namely MC-DCT (Multiple Choice Discourse Completion Tasks) to measure politeness in language and an instrument to describe the factors that affect students' linguistic politeness. The results show that the majority of students (70\%) were included in the "less polite". The lack of courtesy of students due to the politeness of the language used between students has a lower level of politeness than the ideal politeness (completely polite) and social distance (social distance) of students with other individuals also results in a level of politeness.
\end{abstract}

Article Info

Keywords: Linguistic Politeness, Friendliness, Social Interactions

\begin{abstract}
A bstrak
Kesantunan berbahasa merupakan suatu keterampilan yang penting dimiliki setiap indvidu untuk dapat mencapai kesuksesan dan keharmonisan dalam hidup. Kesantunan berbahasa berkaitan dengan keterampilan individu dalam menyesuaikan bahasa pada saat berinteraksi dengan individu lain. Dalam perspektif lain, kesantunan berbahasa merupakan bagian dari character strength dalam psikologi positif yaitu keramahan (agreeableness). Tujuan penelitian kesantunan berbahasa yaitu mendeskripsikan gambaran kesantunan berbahasa siswa sebagai salah satu bentuk keterampilan interaksi sosial. Metode penelitian yang digunakan yaitu deskriptif kuantitatif kepada siswa kelas X sebanyak 191 orang menggunakan instrumen penelitian MC-DCT (Multiple Choice Discourse Completion Tasks). Hasil penelitian menunjukkan kondisi siswa mayoritas (70\%) berada pada kategori kurang santun. Kurang santunnya siswa diakibatkan oleh kesantunan berbahasa yang digunakan antar siswa memiliki tingkat kesantunan yang lebih rendah dari kesantunan ideal (completely polite) serta jarak sosial (social distance) siswa dengan individu lain juga berakibat pada tingkat kesantunan berbahasa.
\end{abstract}

Kata Kunci : Kesantunan Berbahasa, Keramahan, Interaksi Sosial

\section{Naskah Diterima : 2019-07-23}

Naskah Direvisi: 2019-08-21

Naskah Disetujui: 2019-09-11 


\section{A. PENDAHULUAN}

Kesantunan berbahasa merupakan hal penting untuk diaplikasikan dalam kehidupan sehari-hari individu yang tidak pernah terlepas dari interaksi sosial. Melalui kesantunan berbahasa, individu mampu 1) mencapai kehidupan harmonis; 2) meminimalkan konflik yang biasanya terjadi antar individu; 3) meminimalkan terjadinya friksi; serta 4) merupakan kunci keberhasilan seorang individu dalam berkomunikasi dengan individu lainnya (Rohali, 2011, hlm. 77; Widyahening, Ch. E. T, 2011, hlm. 293). Dengan kata lain, kesantunan berbahasa merupakan aspek yang harus dimiliki oleh setiap individu agar dapat mencapai kesuksesan hidup dan mampu menebarkan kedamaian dalam kehidupan setiap individu.

Sebagai keterampilan sosial, kesantunan berbahasa perlu diaplikasikan dalam setiap lingkup kehidupan serta dalam latar pendidikan, karena kesantunan ini termasuk perilaku yang dapat membantu siswa menuju pencapaian tugas perkembangan pribadi dan sosialnya. Individu yang mengaplikasikan kesantunan berbahasa dapat dilihat dari dua aspek, yaitu aspek perilaku dan aspek penggunaan bahasa itu sendiri. Perilaku yang ditunjukkan individu yang mengaplikasikan kesantunan berbahasa misalnya mengucapkan salam kepada orang yang lebih tua, menghormati kepada yang lebih tua, dan tidak memiliki sikap sombong (Ujiningsih, dalam Permadani, 2016, hlm. 2). Dilihat dari segi penggunaan bahasa, individu yang mengaplikan kesantunan berbahasa akan menunjukan beberapa hal yang sesuai dengan maksim kesantunan berbahasa yang dikemukakan Leech G. N, (2005, hlm. 6) di antaranya penggunaan bahasa yang 1) mengutamakan kearifan bahasa; 2) mengutamakan keuntungan orang lain dan kerugian untuk diri sendiri; 3) mengutamakan rasa hormat pada orang lain dan rasa kurang hormat pada diri sendiri; 4) mengutamakan pujian pada orang lain dan rasa rendah hati pada diri sendiri; 5) mengutamakan kecocokan pada orang lain; dan 6) mengutamakan rasa simpati pada orang lain.

Individu yang tidak mengaplikasikan kesantunan berbahasa berarti tidak mampu menghargai orang lain dan dengan bahasa yang tidak santun, individu dapat menyebabkan konflik dengan individu lain. Sauri (2003) menyatakan masih banyak masyarakat Indonesia yang menggunakan kata-kata bebas tanpa didasari pertimbangan moral, nilai, maupun agama. Akibatnya lahir berbagai pertentangan dan perselisihan bahkan berujung pada kekerasan. Dahlan, (dalam Sauri, 2010, hlm. 196) menyatakan bahwa banyak individu yang tersinggung oleh kata-kata yang tajam, dan salah satu contohnya yang diungkapkan Wahid (dalam Sauri, 2010) yaitu tersinggungnya Presiden RI ke-4 oleh diplomat Belanda, Australia, dan Inggris dalam hal diplomasi tanpa sopan santun.

Dalam lingkup kehidupan siswa di sekolah, kesantunan berbahasa belum diaplikasikan sepenuhnya dan hal tersebut diakibatkan oleh beberapa hal. Roshita (2015 hlm. 66) menyatakan banyaknya siswa yang kurang memiliki kesantunan berbahasa diakibatkan oleh lingkungan pergaulan siswa yang banyak menggunakan bahasa kurang santun terhadap sesama sehingga berakibat pada perilaku dan bahasa yang digunakan siswa kepada orang tua dan guru di sekolah. Perilaku yang nampak dari individu yang tidak mengaplikasikan kesantunan berbahasa di antaranya yaitu 1) tidak memandang wajah lawan bicara; 2) menggunakan bahasa yang kasar disaat berbicara kepada orang yang lebih tua; dan 3) berbicara dengan suara yang tidak jelas (Permadani, E. D. L, dkk, 2016, hlm. 2). 
Berdasarkan pemaparan mengenai fenomena kesantunan berbahasa, penelitian ini dilakukan untuk mendeskripsikan secara empirik mengenai gambaran kesantunan berbahasa siswa, terutama menjawab pertanyaan penelitian Bagaimana kecenderungan kesantunan siswa di SMA?

\section{B. TINJAUAN PUSTAKA \\ 1. Kesantunan Berbahasa}

Terdapat berbagai definisi mengenai kesantunan berbahasa, Brown dan Levinson (dalam Culpeper, 2011, hlm. 2) menyatakan bahwa kesantunan berbahasa seperti aturan diplomatik (yang menjadi model) mengisyaratkan bahwa hal itu kemungkinan berusaha untuk menghilangkan agresi, dan memungkinkan komunikasi antara pihak yang berpotensi melakukan perilaku agresif. Kesantunan berbahasa juga dapat diartikan sebagai upaya untuk meminimalkan adanya upaya konfrontasi terhadap suatu wacana (Lakoff, dalam Culpeper, 2011, hlm. 2). Leech (2014, hlm. 3) menyatakan kesantunan berbahasa sebagai suatu bentuk ucapan atau perilaku sebagai salah satu cara untuk memberikan manfaat atau penghargaan yang bukan hanya untuk diri sendiri, tetapi untuk orang lain.

Leech (2014, hlm. 3) selanjutnya menyatakan karaketeristik kesantunan berbahasa bukan merupakan suatu kewajiban (obligatory); terdapat beberapa tingkatan perilaku santun dan tidak santun; terdapat perasaan tentang hal normal yang dilakukan anggota masyarakat; kesantunan yang terjadi akan bergantung pada situasi; adanya timbal balik asimetri antara dua pihak; kesantunan dapat ditunjukkan dalam perilaku berulang; kesantunan melibatkan beberapa jenis transaksi nilai antara dua pihak; dan cenderung mempertahankan keseimbangan nilai antara dua pihak yang terlibat.

Bagi Brown dan Levinson (dalam Holtgraves dan McNamara, 2010, hlm. 179), kesantunan berbahasa pada dasarnya merupakan sarana linguistik untuk mencapai citra diri seorang individu. Kesantunan berbahasa ini dapat berupa perilaku atau tindakan, cara berbusana dan dalam bentuk ucapan atau bahasa (Mislikhah, 2014, hlm. 288).

Brown dan Levinson (dalam Jaworski dan Coupland, 2014) mengungkapkan dua jenis kesantunan berbahasa yaitu kesantunan positif (positive politeness) dan kesantunan negatif (negative politeness). Kesantunan positif berorientasi pada citra diri positif yang menunjukkan rasa hormat terhadap diri dan orang lain, sedangkan kesantunan negatif biasanya didasarkan pada penghindaran. Pembicara mengakui dan menghormati citra diri negatif dari penerima pesan atau pendengar dan tidak mengganggu kebebasan tindakan penerima pesan. Dalam pendekatan postpragmatis, kesantunan berbahasa bukan hanya berupa pandangan normatif atau pandangan pragmatis, tetapi juga merupakan suatu kesepakatan di antara pembicara dan pendengar.

Kesantunan dalam berbahasa erat kaitannya dengan kemampuan individu dalam mengungkapkan berbagai kalimat dalam pola klausa kompleks (Wacewicz, dkk. 2015, hlm. 83). Hal ini dapat dipahami kesantunan berbahasa bukan hanya dalam hal penggunaan bahasa yang santun, namun juga kemampuan dalam memilih dan mengungkapkan beragam kalimat sesuai dengan konteks komunikasi.

\section{Karakteristik Kesantunan Berbahasa}

Berikut ini merupakan beberapa karakteristik kesantunan berbahasa menurut Leech, G (2014, hlm. 5-9). 
1) Bukan merupakan suatu kewajiban, individu dapat menjadi tidak santun meskipun terdapat beberapa alasan yang mengharuskan individu untuk mengaplikasikan kesantunan.

2) Terdapat berbagai jenis tingkatan perilaku santun dan tidak santun

3) Biasanya terdapat perasaan tentang hal normal yang dilakukan oleh anggota masyarakat.

4) Kesantunan yang terjadi akan bergantung pada situasi, seperti contoh terdapat beberapa situasi yang bahkan lebih didominasi oleh ketidaksantunan dan kalimat kasar daripada kalimat santun seperti yang diungkapkan Leech, G (2014)

There are activity types where impoliteness dominates over politeness, and indeed part of the rationale of those activity types is that they encourage discourtesy. Examples where rudeness is generally more salient than politeness are: 1) the leader of the opposition questioning the prime minister at "Question Time" in the British House of Commons; 2) certain "reality" TV shows, where contestants are routinely humiliated or are shown being subjected to verbal abuse; 3) training recruits in an army boot camp; 4) interrogation of a prisoner of war or a crime suspect Hostile cross-examination in a court of law; and 5) heckling a speaker at a political meeting (hlm. 5-6).

Dengan demikian sudah jelas pengaplikasian kesantunan berbahasa ini disesuaikan pada situasi atau kondisi yang sedang terjadi.

5) Adanya timbal balik yang asimetri dalam perilaku sopan antara dua pihak.
6) Kesantunan dapat ditunjukan dalam perilaku yang berulang.

7) Kesantunan melibatkan beberapa jenis transaksi nilai antara pembicara dan pihak lain/orang lain.

8) Cenderung mempertahankan keseimbangan nilai antara dua pihak.

\section{Prinsip/Maksim Berbahasa}

Kesantunan

Maksim dari segi bahasa dapat diartikan sebagai prinsip, pengertian ini berdasarkan ungkapan Grice (dalam Leech, G, 2014, hlm. 12) maksim hanyalah suatu manifestasi khusus dari prinsip. Dengan demikian, dapat dipahami maksim juga dimaknai sebagai suatu prinsip.

Prinsip kesantunan berbahasa terbagi menjadi enam jenis sebagai berikut.

1. Prinsip kebijaksanaan

2. Prinsip kedermawanan

3. Prinsip pujian

4. Prinsip kerendahan hati

5. Prinsip kesepakatan

6. Prinsip kesimpatisan

Berdasarkan definisi kesantunan berbahasa, dapat dipahami kesantunan merupakan suatu keterampilan individu dalam berinteraksi dengan individu lain. Keterampilan interaksi sosial yang diwujudkan dalam kesantunan berbahasa merupakan salah satu tugas perkembangan pada masa remaja yaitu mengebangkan keterampilan komunikasi interpersonal dan belajar bergaul dengan teman sebaya atau orang lain secara individual atau kelompok (William Kay dalam Jahja, Y, 2013, hlm. 238). Dalam sumber lain disebutkan tugas perkembangan masa remaja pada aspek pribadi-sosial salah satunya adalah memiliki kemampuan berinteraksi sosial dan bersikap respek terhadap orang lain, menghormati dan menghargai, serta tidak melecehkan harga diri orang lain (Depdiknas, 2008, hlm. 198). Hal tersebut 
merupakan salah satu tujuan dari kesantunan berbahasa yaitu sebagai upaya untuk menghargai individu lain.

\section{METODE PENELITIAN}

Penelitian mengggunakan metode desktiptif kuantitatif dengan desain survei. Penelitian dilakukan kepada siswa kelas $X$ SMA Negeri 1 Lembang menggunakan teknik random sampling kepada sampel sebanyak 191 siswa. Instrumen yang digunakan dalam penelitian yaitu MC-DCT (Multiple Choice Discourse Competion Tasks) yang merupakan instrumen untuk penelitian pragmatik.

Analisis data dalam penelitian terdiri dari verifikasi data untuk menyeleksi atau memilih data yang memadai; penskoran data untuk intrumen MC-DCT dengan rentang skor 1 sampai 3 dengan rincian pada tabel berikut.

Tabel 1

Penskoran Item Instrumen MC-DCT Kesantunan Berbahasa

\begin{tabular}{clc}
\hline No & Alternatif Pilihan Jawaban & Skor \\
\hline 1. & Bahasa Santun & 3 \\
\hline 2. & Bahasa Santai (Kurang Santun) & 2 \\
\hline 3. & Bahasa Tidak Santun & 1 \\
\hline
\end{tabular}

Kegiatan lainnya dalam proses analisis data yaitu pengkategorian dan penafsiran data. Kategori untuk kesantunan berbahasa siswa dilakukan dengan menggunakan rumus kategori dari data hasil pengolahan model Rasch yaitu nilai mean measure person dan nilai standar deviasi. Berikut pengkategorian kesantunan berbahasa.

Tabel 2

Pengkategorian Kesantunan Berbahasa

\begin{tabular}{cccc}
\hline \multirow{3}{*}{ M (mean measure) } & Kategori & Rumus & Kategori Umum \\
\cline { 2 - 4 }$=.93$ & Santun (polite) & $\mathrm{X} \geq \mathrm{M}+1 \mathrm{SD}$ & $\mathrm{X} \geq 1.61$ \\
\cline { 2 - 4 } $\mathrm{SD}=.68$ & Kurang Santun (less & $\mathrm{M}-1 \mathrm{SD}<\mathrm{X}<\mathrm{M}+$ & $0.25<\mathrm{X}>1.61$ \\
& polite) & $1 \mathrm{SD}$ & \\
\cline { 2 - 4 } & Tidak Santun (impolite) & $\mathrm{X}<\mathrm{M}-1 \mathrm{SD}$ & $\mathrm{X}<0.25$ \\
\hline
\end{tabular}

\section{HASIL DAN PEMBAHASAN}

Hasil penelitian menunjukkan kesantunan berbahasa mayoritas siswa kelas $\mathrm{X}$ berada pada kategori kurang santun didasarkan pada kondisi kelompok. Berikut ini adalah grafik distribusi frekuensi siswa berdasarkan kategori kesantunan. 


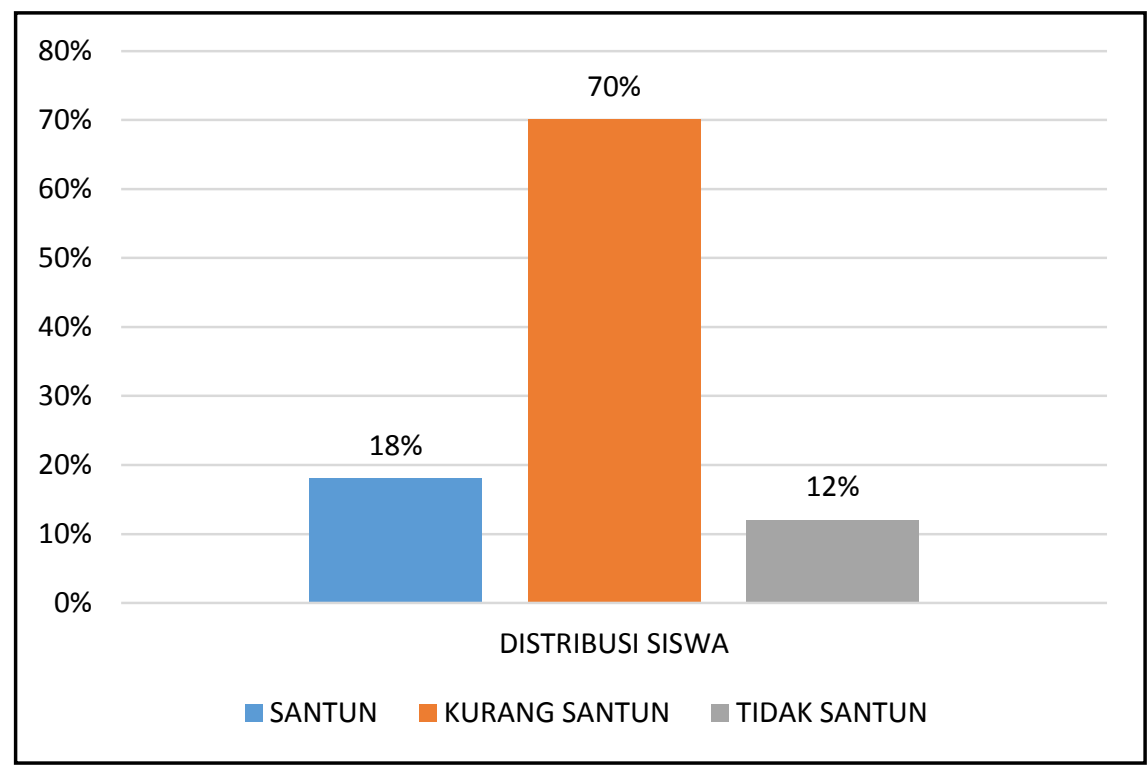

Gambar 1

Grafik Distribusi Frekuensi Siswa berdasarkan Kategori Kesantunan

Berdasarkan Grafik 1 dipahami mayoritas siswa berada pada kategori kurang santun artinya siswa cenderung belum konsisten mengaplikasikan kesantunan berbahasa sesuai dengan prinsip kesantunan Leech. Dengan kata lain, pada situasi tertentu siswa melanggar prinsip-prinsip kesantunan dan pada situasi lain siswa telah dapat mengaplikasikan prinsip kesantunan.

Leech, G (2014, hlm. 5) menyatakan individu dapat menjadi tidak santun atau kasar ketika berhadapan atau berkomunikasi dengan individu lain yang pantas menerima ketidaksantunan atau kekasaran tersebut. Sesuai dengan karakteristik kesantunan, kurang santunnya siswa disebabkan oleh bahasa yang digunakan siswa cenderung kurang santun (bahasa santai) pada saat berkomunikasi dengan siswa lain didasarkan pada kriteria kesantunan yang ideal (completely polite). Namun pada situasi-situasi tertentu, siswa menjadi santun seperti pada saat berkomunikasi dengan guru atau dengan orang yang lebih tua.
Kesantunan berbahasa juga merupakan salah satu keterampilan interaksi sosial yang diwujudkan dalam penggunaan bahasa sesuai dengan tujuan bimbingan dan konseling aspek pribadi-sosial (Depdiknas, 2008, hlm. 198). Kesantunan berbahasa sesuai dengan definisinya berkaitan dengan hubungan sosial yang didalamnya terdapat perilaku simpatis dan empatis, penghargaan terhadap orang lain, serta usaha untuk meminimalkan adanya konflik melalui perilaku berupa ucapan yang lebih mengutamakan dan memberikan manfaat untuk orang lain.

Pada masa remaja salah satu tugas perkembangan yang perlu dicapai berkaitan dengan keterampilan berkomunikasi interpersonal. Pada saat berkomunikasi, individu menggunakan berbagai media atau alat baik secara verbal maupun nonverbal. Secara verbal individu menggunakan bahasa sebagai alat untuk menyampaikan pesan. Jenis bahasa yang digunakan oleh remaja berbeda dengan bahasa yang digunakan anak atau orang dewasa. Sesuai dengan perkembangan bahasa remaja, 
penggunaan ironi, metafora dan permainan kata menjadi hal yang disenangi remaja. Pada masa perkembangannya, remaja juga telah terampil berbicara dalam kalimat yang mengandung dialek atau variasi bahasa yang memiliki kosa kata, tata bahasa, dan pengucapan yang khas (Santrock, 2007), termasuk di dalamnya ragam bahasa santun dan tidak santun.

Santun berbahasa pada dasarnya merupakan salah satu ciri dari sikap bahasa yang dikemukakan Garvin dan Mathiot yaitu kesadaran akan adanya norma bahasa (Chaer, A dan Agustina, L, 2010, hlm. 152). Kesadaran akan adanya norma bahasa mendorong individu untuk menggunakan bahasa dengan cermat dan santun yang merupakan faktor terbesar pengaruhnya terhadap perbuatan yaitu penggunaan bahasa (language use). Siswa santun dapat dikatakan sebagai individu yang sadar akan norma bahasa sehingga mereka mempraktikkannya dalam kehidupan sehari-hari. Dengan memahami norma bahasa, berarti individu memahami bahwa individu lain pantas menerima ucapan atau perilaku yang sesuai norma sehingga konflik yang diakibatkan oleh ketidaksantunan berbahasa tidak akan terjadi. Kondisi tersebut membawa individu pada kesuksesan dalam interaksi dengan individu lain.

Selain menunjukkan kesadaran akan adanya norma bahasa, individu yang santun merupakan salah satu ciri individu yang memiliki mental yang sehat. Salah satu ciri mental yang sehat yaitu memiliki perasaan empati dan rasa kasih sayang terhadap orang lain, senang memberikan pertolongan kepada orang yang memerlukan pertolongan (sikap altruis), serta mampu berhubungan dengan orang lain secara sehat, penuh kasih dan persahabatan (Yusuf, S, 2004, hlm. 22). Santun berbahasa juga merupakan suatu bentuk sikap positif yang menunjukkan adanya rasa kasih sayang dan pemberian bantuan dalam bentuk ucapan sesuai dengan prinsip-prinsip kesantunan berbahasa. Berdasarkan prinsip-prinsip kesantunan berbahasa, individu santun akan memiliki sikap altruis, rendah hati, penuh kasih, dan menciptakan hubungan sehat melalui ucapan yang meminimalkan rasa sakit hati atau kerugian orang lain yang dapat menghambat terjadinya hubungan sosial yang sehat antar individu. Dalam perspektif bimbingan dan konseling merupakan salah satu perilaku etis yang juga perlu diaplikasikan oleh setiap individu. Kesantunan juga merupakan salah satu wujud dari aspek dalam bidang sosial yaitu berempati terhadap kondisi orang lain; menghormati dan menghargai orang lain; serta wujud interaksi sosial yang efektif (Kemendikbud, 2016, hlm. 36). Dengan kesantunan berbahasa, individu menjadi lebih simpati atau empati terhadap kondisi orang lain, hal ini sesuai dengan prinsip kesantunan berbahasa yaitu prinsip kesimpatisan. Prinsip kesimpatisan ini mengutamakan rasa simpati terhadap orang lain dan meminimalkan antipati terhadap orang lain yang dinyatakan dalam ucapan (Leech, G, 2014, hlm. 35).

Berdasarkan penjelasan di atas dapat dipahami kesantunan berbahasa merupakan suatu keterampilan yang penting untuk diaplikasikan oleh setiap individu dan individu yang tidak santun dapat dikatakan sebagai individu yang tidak mampu menghargai, menghormati, dan bersikap simpati terhadap individu lain. Santun tidaknya siswa dipengaruhi oleh beberapa hal, di antaranya yaitu 1) didikan orang tua dalam mengaplikasikan kesantunan berbahasa (Kasper, G, 1990; Wahyudi, D dan Arsana, I.M, 2014); 2) lingkungan pergaulan siswa (Roshita, 2015); 3) norma atau aturan suatu kelompok masyarakat (Muslich, M, dalam Room, R, 2013); 4) kondisi kecemasan tinggi dan masalah perilaku agresif tinggi 
(Pedlow, R, dkk, 2004); dan 5) pemahaman akan prinsip kesantunan berbahasa (Huang, 2008).

Berikut kesantunan berbahasa siswa berdasarkan prinsip kesantunan berbahasa.

\section{Prinsip Kebijaksanaan}

Prinsip ini berkaitan dengan upaya mengutamakan ucapan yang memberi keuntungan kepada orang lain dan meminimalkan ucapan yang merugikan orang lain. Contoh ucapan yang menandakan prinsip kebijaksanaan yaitu "Silakah dicoba teman-teman, itu hadiah dari mamah saya!" Ucapan tersebut menyiratkan pemberian keuntungan tanpa menyebabkan kerugian kepada individu lain.

Pengkategorian tingkat kesantunan berbahasa pada setiap siswa dilihat berdasarkan nilai mean measure person yaitu tingkat kemampuan/tingkat kesantunan siswa dari hasil pengolahan data di model Rasch sebagai berikut.

Tabel 3

Distribusi Frekuensi Siswa dalam Aspek Kebijaksanaan

\begin{tabular}{|c|c|c|c|}
\hline \multirow[b]{3}{*}{$\begin{array}{c}M \text { (mean measure })= \\
1.47 \\
\mathrm{sn}-1.18\end{array}$} & Kategori & Kategori & Jumlah Siswa \\
\hline & Santun (polite) & $X \geq 2.65$ & 28 siswa $(15 \%)$ \\
\hline & $\begin{array}{c}\text { Kurang Santun (less } \\
\text { polite) }\end{array}$ & $0.29<X<2.65$ & 139 siswa $(72 \%)$ \\
\hline & $\begin{array}{l}\text { Tidak Santun } \\
\text { (impolite) }\end{array}$ & $X<0.29$ & 24 siswa (13\%) \\
\hline & Jumlah Total Siswa & & 191 siswa \\
\hline
\end{tabular}

Berdasarkan kategori nilai tersebut dihasilkan mayoritas siswa berada pada kategori kurang santun pada aspek kebijaksanaan yaitu sebanyak 139 orang siswa. Dengan demikian, dapat dipahami siswa lebih sering menggunakan bahasa kurang santun ketika berinteraksi dengan orang lain atau dalam situasi terntentu siswa memberikan respons yang melanggar aspek kebijaksanaan. Selain itu siswa yang berada pada kategori tidak santun sebanyak 24 siswa yang memberikan respons ucapan pada beberapa situasi yang melanggar prinsip kebijaksanaan. Artinya 13\% siswa masih mengucapkan kalimat yang memberi kerugian kepada orang lain dan cenderung mengungkapkan kalimat yang memaksa. Pada saat individu melanggar prinsip kesantunan ini, seseorang akan dianggap tidak santun karena pada dasarnya prinsip kebijaksanaan ini dapat meminimalkan perasaan sakit hati sebagai akibat dari perlakuan yang tidak menguntungkan (Rohali, 2011, hlm. 77).

Sesuai dengan prinsip kebijaksanaan dalam kesantunan, individu yang santun adalah individu yang berupaya untuk memberikan keuntungan kepada orang lain dan meminimalkan ucapan yang merugikan orang lain. Hal ini sesuai dengan konsep kebijaksanaan dalam psikologi positif yang juga memberikan manfaat untuk diri individu dan orang lain dan kebijaksanaan ini ditunjukkan dalam keterampilan interpersonal seperti kemampuan untuk mendengarkan, mengevaluasi, dan memberi nasihat.

\section{Prinsip Kedermawanan}

Prinsip kedermawanan berkaitan dengan keterampilan untuk meinimalkan 
ucapan yang memberi keuntungan pada diri sendiri dan meningkatkan ucapan yang menandakan pengorbanan diri sendiri. Contoh kalimat pada prinsip kedermawanan yaitu "Boleh, tapi saya hanya dapat membantu kamu sebentar karena perlu istirahat". Kalimat tersebut menandakan pengorbanan seorang siswa yang bersedia membantu siswa lain meski dalam kondisi kurang sehat. Berikut kategori tingkatan kesantunan berbahasa siswa pada aspek kedermawanan.

Tabel 4

Distribusi Frekuensi Siswa dalam Aspek Kedermawanan

\begin{tabular}{cccc}
\hline \multirow{2}{*}{$\begin{array}{c}\text { M (mean } \\
\text { measure) }=.95 \\
\text { SD = 1.34 }\end{array}$} & Kategori & Kategori & Jumlah Siswa \\
\cline { 2 - 4 } & Kurang Santun (less polite) & $-0,39<\mathrm{X}<2.29$ & 39 siswa $(20 \%)$ \\
\cline { 2 - 4 } & Tidak Santun (impolite) & $\mathrm{X}<-0,39$ & 141 siswa $(74 \%)$ \\
\hline & Jumlah Total Siswa & & 11 siswa $(6 \%)$ \\
\hline
\end{tabular}

Mayoritas siswa pada aspek kedermawanan cenderung berada pada kategori kurang santun, berarti siswa cenderung menggunakan bahasa yang kurang santun ketika berinteraksi dengan orang lain termasuk orang yang berbeda usia. Sedangkan sebanyak $6 \%$ siswa melanggar prinsip kedermawanan. Artinya siswa masih mengutamakan keuntungan diri sendiri dibandingkan dengan pengorbanan diri sendiri ketika menghadapi kesulitan orang lain.

Ucapan yang menunjukkan pengorbanan diri dalam prinsip kedermawanan menunjukkan sikap individu yang senang membantu dan memberi perhatian kepada individu lain. Dalam perspektif psikologi, prinsip kedermawanan ini menandakan sikap kebaikan (kindness). Kindness merupakan sikap yang menjadikan individu bermurah

\section{Tabel 5}

\section{Distribusi Frekuensi Siswa dalam Aspek Pujian}

\begin{tabular}{|c|c|c|c|}
\hline \multirow{4}{*}{$\begin{array}{c}M(\text { mean } \\
\text { measure })=1.52 \\
S D=1.43\end{array}$} & Kategori & Kategori & Jumlah \\
\hline & Santun (polite) & $X \geq 2,95$ & 33 siswa (17\%) \\
\hline & $\begin{array}{l}\text { Kurang Santun (less } \\
\text { polite) }\end{array}$ & $0.09<X<2,95$ & 120 siswa $(63 \%)$ \\
\hline & Tidak Santun (impolite) & $X<0.09$ & 38 siswa $(20 \%)$ \\
\hline & Jumlah Total & & 191 Siswa \\
\hline
\end{tabular}


Mayoritas kesantunan berbahasa siswa pada aspek pujian berada pada kategori kurang santun (120 siswa). Artinya pada situasi tertentu siswa sudah dapat memberikan pujian atas keberhasilan orang lain, namun pada situasi lainnya siswa masih merespons dengan ucapan yang tidak santun atau melanggar prinsip pujian. Siswa yang kurang santun dapat dikatakan belum konsisten dalam mengaplikasikan prinsip pujian ini. Pada saat individu lebih mengutamakan pujian kepada diri sendiri maka individu tersebut menjadi tidak santun.

Pujian dalam konteks bimbingan dan konseling merupakan suatu bentuk perilaku yang dalam teori behavioristik disebut sebagai penguatan positif (positive reinforcement) atau disebut reward. Pujian verbal (reward) yaitu peristiwa positif yang diberikan sebagai suatu balasan dari perilaku individu (Sharf, R. S, 2012, hlm. 285). Penguatan positif sebagai suatu peristiwa yang mengikuti perilaku, dan peristiwa tersebut meningkatkan frekuensi perilaku (Spiegler, dalam Sharf, R. S, 2012, hlm. 285).

\section{Prinsip Kerendahan Hati}

Kerendahan hati pada prinsip kesantunan berbahasa berkaitan dengan keterampilan meminimalkan ucapan yang memuji diri sendiri dan meningkatkan ucapan yang mengecam diri sendiri. Contoh "Hebat sekali, nanti saya mau belajar dengan kamu, boleh? Soalnya saya belum begitu paham". Pada kalimat tersebut ditunjukkan ucapan seseorang yang memberi penghargaan kepada orang lain dan mengakui bahwa dirinya tidak begitu memahami suatu materi pelajaran. Individu rendah hati bukan berarti merendahkan diri tetapi berupaya untuk tidak mengunggulkan diri di hadapan orang lain seperti halnya orang sombong. Kecenderungan kesantunan berbahasa siswa pada aspek kerendahan hati dipaparkan dalam tabel kategori tingkat kesantunan siswa yang didasarkan pada nilai mean measure person dan standar deviasi person. Nilai mean measure pada aspek ini sebesar 1.48 dan nilai standar deviasi sebesar 1.36.

\section{Tabel 6}

Distribusi Frekuensi Siswa dalam Aspek Kerendahan Hati

\begin{tabular}{|c|c|c|c|}
\hline \multirow{4}{*}{$\begin{array}{c}M \text { (mean measure) } \\
=1.48 \\
S D=1.36\end{array}$} & Kategori & Kategori & Jumlah \\
\hline & Santun (polite) & $X \geq 2.84$ & 25 siswa (13\%) \\
\hline & $\begin{array}{l}\text { Kurang Santun (less } \\
\text { polite) }\end{array}$ & $0.12<X<2.84$ & 130 siswa $(68 \%)$ \\
\hline & Tidak Santun (impolite) & $X<0.12$ & 36 siswa (19\%) \\
\hline & Jumlah Total & & 191 Siswa \\
\hline
\end{tabular}

Pada aspek kerendahan hati, mayoritas siswa berbahasa kurang santun (130 siswa). Artinya siswa belum konsisten dalam mengaplikasikan prinsip kerendahan hati atau bahasa yang digunakan adalah bahasa yang kurang santun. Pada situasi tertentu siswa mengungkapkan pujian atau mengunggulkan diri sendiri ketika bertutur atau berbicara dengan orang lain atas keberhasilan dirinya, namun pada situasi lain siswa cenderung mengecam atau rendah hati atas keunggulan yang dimilikinya. Sebagian siswa lain terbagi menjadi kelompok siswa santun sebanyak 25 siswa dan 36 siswa lainnya merupakan kelompok tidak santun. Tidak santun berdasarkan prinsip kerendahan hati 
adalah ketika siswa lebih sering mengunggulkan atau memuji diri sendiri atas keberhasilan atau kelebihan yang dimilikinya. Siswa yang tidak santun berdasarkan prinsip ini disebut juga sombong atau congkak (Rahardi, K, 2005, hlm. 79) karena lebih sering membanggakan atau memuji diri sendiri.

Prinsip kerendahan hati yang berkaitan dengan upaya individu untuk tidak memuji diri sendiri sama seperti halnya karakter humility yang merupakan bagian dari character strength dalam psikologi positif. Peterson dan Seligman (2004, hlm. 436) menyatakan kerendahan hati pada dasarnya lebih bersifat internal, berkaitan dengan keyakinan individu bahwa mereka bukan merupakan pusat dari alam semesta (pusat dari segala hal). Humility berarti memahami bahwa diri individu itu pandai, namun juga tidak mengetahui segalanya. $\mathrm{Hal}$ ini menandakan individu menerima kekuatan/keunggulan dirinya, tetapi juga menyadari bahwa dirinya tidak memiliki kuasa dalam semua hal. Dalam konteks sederhana, humility berarti keyakinan bahwa setiap individu pasti memiliki kelemahan dan kelebihan (Templeton, dalam Synder, C, 2002, hlm. 412).

\section{Prinsip Kesepakatan}

Prinsip kesepakatan berkaitan dengan penggunaan bahasa ketika merespons pendapat orang lain berupa kalimat persetujuan atau kalimat ketidaksetujuan yang disampaikan dengan bahasa santun sehingga tidak menimbulkan kesalahpahaman. Prinsip kesepakatan bukan membatasi siswa untuk berpendapat, namun menekankan pada penggunaan bahasa santun sesuai prinsip kesepakatan ketika siswa mengungkapkan pendapat pribadi atau memberikan respons pada pendapat orang lain.

\section{Tabel 7}

Distribusi Frekuensi Siswa dalam Aspek Kesepakatan

\begin{tabular}{cccc}
\hline & Kategori & Kategori & Jumlah \\
\cline { 2 - 4 } M (mean measure) & Santun (polite) & $\mathrm{X} \geq 2.27$ & 20 siswa (10\%) \\
\cline { 2 - 4 }$=\mathbf{1 . 0 2}$ & Kurang Santun (less & $-0.23<\mathrm{X}<2.27$ & 164 siswa (86\% \\
SD =1.25 & polite) & & \\
& & $\mathrm{X}<-0.23$ & 7 siswa (4\%) \\
\cline { 2 - 4 } & Tidak Santun (impolite) & $\mathbf{1 9 1}$ siswa \\
\hline
\end{tabular}

Berdasarkan Tabel 7 dapat disimpulkan mayoritas siswa (164 siswa) berada pada tingkat kurang santun berdasarkan aspek kesepakatan artinya sebesar $86 \%$ siswa masih belum konsisten berbahasa santun ketika dihadapkan pada situasi tertentu sesuai dengan aspek kesepakatan. Selain itu, sebesar $10 \%$ siswa merupakan siswa santun yang telah mengaplikasikan prinsip kesepakatan ketika bertutur atau berinteraksi dengan orang lain.
Sedangkan sebesar 4\% siswa lainnya melanggar aspek kesepakatan. Artinya siswa merespons pendapat orang lain mengungkapkan kalimat penolakan dengan bahasa tidak santun yang dapat merugikan orang lain.

Prinsip kesepakatan berkaitan dengan kecerdasan sosial yang berfokus pada hubungan individu dengan orang lain termasuk kedekatan dan kepercayaan, bujukan (persuasion), 
keanggotaan kelompok, dan kekuasaan politik (Peterson, C dan Seligman, M, 2004, hlm. 339). Untuk dapat mencapai kesepakatan dengan orang lain, individu perlu memiliki keterampilan dalam mengungkapkan pendapat dan cenderung memiliki toleransi terhadap perbedaan pendapat orang lain. Pada saat mengungkapkan pendapat, individu penting untuk memahami kondisi orang lain dan bersikap bijak ketika berhubungan dengan orang lain. Bijak dalam hubungan dengan orang lain merupakan salah satu kecerdasan sosial sesuai dengan pernyataan Peterson, C dan Seligman, M (2004, hlm. 339) yaitu bertindak dengan bijak dalam sebuah hubungan merupakan salah satu bentuk kecerdasan sosial.

Contoh :

Situasi : Temanmu mengusulkan untuk belajar kelompok di rumahnya. Apa yang akan kamu ucapkan?

a. Rumah kamu jauh, itu hanya akan membuang waktu kita (tidak santun)

b. Saya setuju, kita juga bisa lebih nyaman belajarnya (santun) c. Aku setuju, karena di rumahmu banyak makanan tentunya (kurang santun)

Untuk dapat mencapai kesepakatan dengan orang lain, individu perlu memiliki keterampilan dalam mengungkapkan pendapat dan cenderung memiliki toleransi terhadap perbedaan pendapat orang lain. Pada saat mengungkapkan pendapat, individu penting untuk memahami kondisi orang lain dan bersikap bijak ketika berhubungan dengan orang lain. Bijak dalam hubungan dengan orang lain merupakan salah satu kecerdasan sosial (Peterson, C dan Seligman, M, 2004, hlm. 339).

\section{Prinsip Kesimpatisan}

Kesimpatisan berkaitan dengan keterampilan untuk mengucapkan kalimat yang simpatis ketika melihat atau menghadapi kesulitan atau kebahagiaan orang lain. Individu disebut santun pada saat mampu mengucapkan kalimat yang simpatis. Berikut distribusi frekuensi siswa dalam kategori kesantunan berdasarkan aspek kesimpatisan.

Tabel 8

Distribusi Frekuensi Siswa dalam Aspek Kesimpatisan

\begin{tabular}{|c|c|c|c|}
\hline \multirow{4}{*}{$\begin{array}{c}M(\text { mean } \\
\text { measure })=0.72 \\
S D=1.00\end{array}$} & Kategori & Kategori & Jumlah \\
\hline & Santun (polite) & $X \geq 1.72$ & 18 siswa $(9 \%)$ \\
\hline & Kurang Santun (less polite) & $-0.28<X<1.72$ & 155 siswa (82\%) \\
\hline & Tidak Santun (impolite) & $X<-0.28$ & 18 siswa (9\%) \\
\hline & Jumlah Total & & 191 siswa \\
\hline
\end{tabular}

Pada aspek kesimpatisan, mayoritas siswa (155 siswa) cenderung kurang santun. Siswa masih mengungkapkan kalimat yang tidak simpatis ketika dihadapkan pada kesulitan orang lain, namun siswa juga mengungkapkan kalimat simpatis pada kondisi lainnya. Selain itu sebesar 9\% siswa merupakan siswa santun yang telah mengaplikasikan prinsip kesimpatisan pada berbagai situasi. Sebesar 9\% siswa juga secara konsisten melanggar aspek kesimpatisan. Artinya siswa cenderung mengungkapkan kalimat antipati ketika merespons berbagai situasi.

Santun tidaknya individu pada prinsip kesimpatisan bergantung pada simpatis tidaknya individu terhadap kondisi individu lain. Antipati terhadap orang lain merupakan suatu perlaku tidak 
santun (Rahardi, K, 2005, hlm.65). Berdasarkan hal tersebut individu yang menunjukkan rasa simpatis ketika bertutur merupakan individu santun yang sesuai dengan prinsip kesimpatisan. Rasa simpatis ditunjukkan dalam pemilihan bahasa ketika individu memberikan respons terhadap kondisi orang lain, baik kondisi positif atau negatif.

Contoh,

Situasi : Temanmu mengatakan kalau dia baru kehilangan dompetnya. Apa yang kamu ucapkan selanjutnya?

a. "Saya ikut sedih, bagaimana kalau nanti kita membuat pengumuman barang hilang, semoga saja ada yang menemukan" (santun)

b. "Aku ikut sedih, nanti kamu pinjam dulu aja uang buat ongkos pulang" (kurang santun)

c. "Kamu buat pengumuman aja, siapa tahu ada teman lain yang nemuin" (tidak santun)

Kesimpatisan dalam perspektif psikologi positif termasuk perilaku prososial. Kesimpatisan merupakan orientasi emosi lain yang pada umumnya didefinisikan sebagai 1) kemampuan untuk mengalami kondisi emosi/perasaan orang lain atau 2) memiliki rasa belas kasih dan prihatin terhadap kondisi orang lain (Peterson, C dan Seligman, M, 2004, hlm. 330). Kesimpatisan dalam prinsip kesantunan berbahasa juga menunjukkan keterampilan individu untuk turut merasakan kondisi orang lain yang ditunjukkan dalam bentuk ucapan. Ketika individu dihadapkan dengan kesedihan atau masalah yang dialami oleh individu lain, individu santun memiliki keterampilan untuk mengungkapkan ucapan simpatis terhadap kondisi orang lain tersebut.

\section{E. KESIMPULAN}

Kesantunan berbahasa merupakan suatu keterampilan untuk memberikan manfaat dan menghargai orang lain. Kesantunan berbahasa berkaitan dengan penggunaan bahasa pada saat individu berinteraksi dengan individu lain dalam kehidupan sehari-hari. Hasil penelitian menunjukkan kesantunan berbahasa mayoritas siswa kelas $\mathrm{X}$ berada pada kategori kurang santun berdasarkan kondisi kelompok. Kondisi kesantunan berbahasa siswa dipengaruhi oleh beberapa hal dan salah satunya ialah penggunaan bahasa siswa pada saat berinteraksi dengan siswa lain cenderung memiliki tingkat kesantunan yang lebih rendah dari tingkat kesantunan ideal (completely polite).

Kesantunan berbahasa individu dapat dilihat dari beberapa prinsip kesantunan Leech yaitu prinsip kebijaksanaan, kedermawanan, pujian, kerendahan hati, kesepakatan, dan prinsip kesimpatisan. Masing-masing prinsip kesantunan berbahasa berkaitan dengan beberapa jenis character strength dalam psikologi positif dan kesantunan berbahasa merupakan salah satu jenis keramahan (agreeableness) 


\section{DAFTAR PUSTAKA}

Culpeper, J. (2011). Politeness and impoliteness. Handbooks of Pragmatics, 5(1), hlm. 1-41. Depdiknas. (2008). Penataan pendidikan profesional konselor dan layanan bimbingan dan konseling dalam jalur pendidikan formal. Jakarta : Departemen Pendidikan Nasional.

Holtgraves, T., \& McNamara, P. (2010). Pragmatic comprehension deficit in Parkinson's disease. Journal of Clinical and Experimental Neuropsychology, 32(4), 388-397.

Jahja, Y. (2013). Psikologi perkembangan. Jakarta : Kencana Prenadamedia Group.

Jaworski, A., \& Coupland, N. (Eds.). (2014). The discourse reader (Vol. 2). Nueva York, NY: Routledge.

Kasper, G. (1990). Linguistic politeness. Journal of Pragmatics. 14(1), hlm. 193-218.

Leech, G. N. (2005). Politeness : is there an east-west divide?. Journal of Foreign Language. 1(6), hlm. 1-30.

Leech, G. N. (2014). The pragmatics of politeness. New York : Oxford University Press.

Permadani, E. D. L. (2016). Peningkatan Perilaku Sopan Santun Anak Melalui Metode Sosiodrama pada Kelompok B TK Negeri Pembina Kecamatan Pringkuku Tahun Ajaran 2015/2016 (Doctoral dissertation, Universitas Sebelas Maret).

Rohali. (2011). Kesantunan bahasa sebagai pilar pendidikan karakter : perspektif sosiopragmatik. Jurnal Pendidikan Karakter. 1(1), hlm. 74-86.

Roshita, I. (2015). Upaya meningkatkan perilaku sopan santun melalui layanan bimbingan kelompok dengan teknik sosiodrama. Jurnal Penelitian Tindakan Bimbingan dan Konseling. 1(1), hlm. 64-70.

Sauri, S. (2003). Pengembangan strategi pendidikan berbahasa santun di sekolah. Mimbar Pendidikan. 1(1), hlm. 45-52.

Sauri, S. (2010). Membangun bangsa berkarakter santun melalui pendidikan nilai di persekolahan. Proceedings of The International Conference on Teacher Education. (hlm. 196-211). Bandung : UPI.

Widyahening, Ch. E. T. (2011). Pentingnya tindak tutur kesantunan siswa kepada guru dalam proses belajar mengajar. Jurnal ilmiah Widya Wacana. 7(3), hlm. 291-298.

Yusuf, S. (2004). Mental hygiene. Bandung : Pustaka Bani Quraisy.

Chaer, A. (2010). Kesantunan Berbahasa. Jakarta: Rineka Cipta.

Gilman, R, dkk. (2008). Handbook of positive psychology in schools. New York : Routledge.

Huang, Y. (2008). Politeness principle in cross-culture communication. English Language Teaching. 1(1), hlm. 96-101.

Kemendikbud. (2016). Panduan operasional penyelenggaraan bimbingan dan konseling sekolah menengah atas. Jakarta : Kementerian Pendidikan dan Kebudayaan.

Pedlow, R, dkk. (2004). Children's production and comprhension of politensess in requests : relationships to behavioral adjustment, temperament and empathy. First Language. 24(3), hlm. 347-367.

Peterson, C dan Seligman, M. E. P. (2004). Character strengths and virtues. New York: Oxford University Press.

Rahardi, K. (2005). Pragmatik : kesantunan imperatif bahasa indonesia. Jakarta : Erlangga.

Rohali. (2011). Kesantunan bahasa sebagai pilar pendidikan karakter : perspektif sosiopragmatik. Jurnal Pendidikan Karakter. 1(1), hlm. 74-86.

Room, R, (2013). Konsep kesantunan berbahasa dalam islam. Jurnal Adabiyah, 13(2), hlm. 223-233.

Santrock, J. W. (2007). Child development, 11th edition (Mila Rahmawati dan Anna Kuswanti). Jakarta : Erlangga. 
Sharf, R . S. (2012). Theories of psychotherapy and counseling : concepts and cases. [5th Edition]. United States of America : Cengange Learning.

Synder, C. R. Dan Lopez, S. J. (2002). Handbook of positive psychology. New York : Oxford University Press.

Wahyudi, D dan Arsana, I. M. (2014). Peran keluarga dalam membina sopan santun anak di desa galis kecamatan galis kabupaten pamekasan. Kajian Moral dan Kewarganegaraan. 1(2), hIm. 290-304.

Wacewicz, S., \& Żywiczyński, P. (2015). Language evolution: why Hockett's design features are a non-starter. Biosemiotics, 8(1), 29-46. 